Ukraine].

18. Makarenko, G.G. (2005). Creativity of the conductor: Aesthetic-art-study dimensions. Kyi'v: Fakt [in

19. Mikhailov, M.K. (1966). On the concept of style in music. Questions of the theory and aesthetics of music. Moskva - Lenyngrad: Muzyka [in Russian].

20. Münsch, S. (1975). I am a conductor. Conductor performance. Moskva Muzyka [in Russian].

21. Olkhov, K.A. (1990). Theoretical Foundations of Conducting Technique. Lenyngrad: Muzyka [in Russian].

22. Pazovsky, A. (1975 Notes of the conductor. Conductor performance. Practice. Story. Aesthetics. Moskva)

347-364 [in Russian].

23. Ptitsa, K. B. (1972 Problems of style and choral performance. Work with the choir. Methods, experience.

M.: Profizdat) 13-56 [in Russian].

24. Rabinovich, D. (1979). Artist and style. M.: Sovetskij kompozitor [in Russian].

25. Rahlin, N. G. (1990). Stat'i. Interv'ju. Vospominanija M.: Sovetskij kompozitor [in Russian]. Ukraine].

26. . Roshok, V. I. (1994). Stefan Turchak: Conductor, artist, citizen. Harkiv: Harkivs'ka mis'ka drukarnja [in

27. Skromnyi, B. Psychology of creativity of the conductor. Author's course of lectures [in Ukraine].

28. Sokhor, A.N. (1966). Style, method, direction (to the definition of concepts). Voprosy teorii i jestetiki muzyki, 4, 3-16 [in Russian].

[in Russian].

29. Chesnokov, P. (1961). The Choir and its Management: A Handbook for Choral Conductors. M. : Muzgiz

30. Yudin, G. Ya. (1977). Beyond the Boundaries of the Last Days: From the Memories of the Conductor. M. : Muzgiz [in Russian].

Стаття надійшла до редакції 12.07.2018 p.

УДК 730.071.1 Arkhypenko:7.03 (100)

Turchak Lesiia

Candidate in Arts Studies,

Arts Department Senior Lecturer,

Kyiv Universityof Culture

ORCID 0000-0002-0490-8732

lessit@ukr.net

\title{
O. ARKHYPENKO'S CREATIVE WORK IN THE CONTEXT OF THE WORLD ART
}

The purpose of the article. The research looks into a coherent picture of the Ukrainian art study within the world context. Methodology of the research grounds on using general scientific methods, theoretical and practical approaches to analysis of the Ukrainian artists' creative work. Scientific novelty of the research is to study the O. Arkhypenko's creative work of abroad. Conclusions: Late XIXth - early XXth century changes in the art have been reflected in the activities of the Ukrainian artists. Their work corresponded not only with world tendencies, but also made its corrections in the fine arts of Europe and the USA. The influence of new concepts, tendencies, and shaping on various types of artistic activity, became one of the main features of the development of sculpture.

Key words: creative work of $O$. Arkhypenko, sculpture, Ukrainian artists, «sculptural painting», «moving painting».

Турчак Леся Іванівна, кандидат мистецтвознавства, старший викладач кафедри мистецтв Київського університету культури

Аворчість О. Архипенка у контексті світового мистецтва

Мета - дослідити творчість О. Архипенка у контексті ії значення для світового мистецтва. Методологія дослідження полягає у використанні загальнонаукових методів, зокрема біографічного, аналізу та синтезу, з опорою на принцип наукової достовірності. Використання методологічних засад мистецтвознавчого і культурологічного підходу дало змогу дослідити основні творчі здобутки О. Архипенка та їх значення для світового пластичного мистецтва та культури загалом. Наукова новизна полягає в досліджені творчості українського митця О. Архипенка за кордоном, що уможливлює фрормування цілісного уявлення про роль і значення українського мистецтва у світовому контексті. Висновки. Зміни в мистецтві кінця XIX - початку XX ст. знайшли своє відображення у діяльності українських митців. Їх творчість відповідала не лише світовим тенденціям, а й внесла свої корективи в образотворче мистецтво Європи та США. Так вплив нових запропонованих ними концепцій, засобів формоутворення тощо на різні види художньої діяльності став однією з головних рис розвитку світової скульптури та пластичних мистецтв загалом.

Ключові слова: творчість О.Архипенка, скульптура, українські митці, «скульптурний живопис», «рухомий живопис».

Турчак Леся Ивановна, кандидат искусствоведения, старший преподаватель кафедры искусств Киевского университета культуры

Творчество А. Архипенко в контексте мирового искусства

Цель - исследовать творчество А. Архипенко в контексте его значения для мирового искусства. Методология исследования заключается в использовании общенаучных методов, в частности биографического, ана-

(c) Turchak L., 2018 
лиза и синтеза, с опорой на принцип научной достоверности. Использование методологических основ искусствоведческого и культурологического подхода позволило исследовать основные творческие достижения А. Архипенко и их значение для мирового пластического искусства и культуры в целом. Научная новизна заключается в исследовании творчества украинского художника А. Архипенко за рубежом, что делает возможным формирование целостного представления о роли и значении украинского искусства в мировом контексте. Выводы. Изменения в искусстве конца XIX - начале XX в. нашли свое отражение в деятельности украинских художников. Их творчество отвечало не только мировым тенденциям, но и внесло свои коррективы в изобразительное искусство Европы и США. Так влияние новых предлагаемых ими концепций, средств формообразования и т.д. на различные виды художественной деятельности стало одной из главных черт развития мировой скульптуры и пластических искусств в целом.

Ключевые слова: творчество А.Архипенко, скульптура, украинские художники, «скульптурная живопись», «подвижная живопись».

The relevance of the article. It has long been known that Ukrainian art is known all over the world. There is a saying: "Our colour is around the world". Moreover, it's true that this metaphor implies that Ukrainians or those having Ukrainian roots are "scattered" around the world.

Of course, such a "cream" includes Ukrainian artists who have become known far beyond Ukraine.

Raising the issue of the study. There are not many researches devoted to the creativity of Ukrainians abroad. M. Holubets (Monograph, 1920), V.S. Nemtsova (article: "The Ukrainian Roots of David Burliuk's Creative Work"), etc. wrote about the fine arts abroad. The Ukrainian song creation of the beginning of the XXth century was described by, in particular O.Koshytsa, as well as by such researches as N.B Kalutska, L. A. Parkhomenko ("Art Activity in the Context of the XX Century Music"), M. Holovashchenko ("The Phenomenon of Olekdandr Koshytsa"), S. Saliy ("Chorus Processing in the Work Of Oleksandr Koshytsa"), etc. Choreographic art, including V. Avramenko's creative activity, is reflected in the researches I. Knysh ("The Living Soul of the People"), I. Pyhuliak ("Vasyl Avramenko and the Revival of the Ukrainian Tank"), etc.

However, there is no coherent picture of Ukrainian art in the world context. This is due to the choice of research topic.

The purpose of this article is to look into the work of Olekdandr Arkhypenko, an outstanding artist, an innovator in the field of sculpture.

The previous researches analysis. Oleskandr Arkhypenko's work is described in the researches: M. Holubets (the first Ukrainian-language monograph on O. Arkhypenko, was published in the "Public Newsletter" journal, 1920), N. Kubrysh (thesis research on "Mythopoetics of O. Arkhypenko and I. Kavaleridze sculptures", 2004), L. Vezhbovska (article on "Sculptor Arkhypenko. His own in Paris, Berlin and New York, a stranger in Kiev", researching the attitude to the sculptor's creativity in Ukraine and the world, 2012), O. Synko (O. Arkhypenko's First Steps, 1994), and others.

The plot of the article. Oleksandr Porfyriiovych Arkhypenko was born in Kyiv on May 30, 1887. From 1902 to 1905 he studied at Kyiv Art School, (been expelled in November 1905 for having participated in a student strike associated with the events of the 1905-1907 revolution). In 1906 he continued his art studies at Serhii Svitoslavskyi, and the same year together with Oleksandr Bogomazov he organized his first exhibition of works in Kyiv. Having moved for Moscow, in 1906-1908 O. Arkhypenenko continued his education at Moscow School of Painting, Architecture and Sculpture. Participating in exhibitions, he got acquainted with V. Kandinsky, L. Popova, A. Pevzner, and N. Gabo.

In 1908, he travelled beyond the borders of the Russian Empire and temporarily settled in Paris where he continued his education at Paris Art School. After moving, the artist was interested in the Louvre works, the "naive" art of Africa.

In Paris O. Arkhypenko established friendship and became colleagues with Picasso, Matisse, Cezanne, Leger, Braque, Chagall, and others.

In the same 1910, the artist travelled with the exhibition of his work by Italy, Sweden, France, Germany, and Czechoslovakia.

The years of the First World War (1914-1918) O. Arkhypenko spent in Nice. Several years (19211923) lived and worked in Germany. In 1921 having married a sculptor Angelica Bruno-Schultz, he moved to the United States of America [5].

Altogether with other well-known European artists, Oleksandr Arkhypenko reflected the creative tendencies of that time, the object of his art was a man and his inner world.

In the vast majority of the artists' compositions, there is kubism, constructivism and abstractionism. Although there is a number of works, in which there appeared some realistic tendencies. This is a series of plastic women's torsos $(1916,1922)$ and portraits (T. Shevchenko, 1923, 1933; I. Franko, 1925; such conductors as W. Mengelberg, 1925; W.Furtwängler, 1927).

O. Arkhypenko created his "image of the female figure", which became recognizable all over the world. Obviously, most sculptures created by the artist, are different from the usual perception of the female figure. It is far from traditional ideas, but it transmits plastic, a form inherent to a woman. These are "A statuette" (1914), "Vase-women" (1918, 1919), "A sitting figure" (1935), "An Arab woman" (1936), "Yellow and black" (1938), "Dualism" (1954), "The Vertical Torso" (1957), "Red" (1957), "A woman on the Chair" (1963). All the sculptures mentioned above have common features: generalization, thighs' roundness, lack of 
facial features, the legs' conical completion [6]. In addition, the artist experimented, changing the subject world into simple geometric forms, combining three-dimensional shapes with planes. Since the innovator appealed to the "simple forms", he was considered a cubist, a recognized founder of Cubism in sculpture. After all, he did not just fall under the influence of the current course - Cubism, but he turned over a steady picture presentation of the sculpture. Been asked about his attitude to Cubism, the artist clarified that along with a group of artists among whom he was the youngest $O$. Arkhypenko collaborated in the creation of Cubism in Paris in 1910. However, the artist also noted that he did not take from Cubism, but added to it [10, 18]. As $O$. Arkhypenko addressed to colour in sculpture, so there appeared a "sculptural painting". It differed from an ordinary polychrome sculpture. As the author stated this painting was created mainly as a panel, combining colours and shapes. Aesthetically, this was a new type of art due to its special interdependence between relief, concave shapes and shapes with holes, colours and textures. Some forms were made of papier mâché, glass, wood or metal, etc. The forms are interspersed with coloured fragments and the space between them, according to a particular aesthetic or spiritual task. The presence of the plot was also possible. Nuances of form and colour and their interdependence were as important and significant as the nuances of sound and silence in music. It was impossible to draw boundaries between colour and the real form, because they were interrelated with respect to aesthetics and technology. The nature is seen to be never separated from the colour, but, for various reasons, united them in infinite variety [9, 26]. Such works include "A Still Life" (1918, tinted papier mâché, wood), "A Sitting Woman" (1919, a sculptor-painting, papier mâché, wood), "The Ocean Madonna" (1957, wood, metal, mosaic, mother-of-pearl)," A Woman" (1963, a relief and tinted design of wood, copper, brass, and melchior).

O. Arkhypenko also experimented with different materials (metal, wood, cardboard, fabric, wire, and glass), often combining non-inverted materials and shapes. The sculptor connected two-dimensional planes with three-dimensional geometric shapes (a cone, a sphere, a cube), painted in bright colours and attached to the board - a background.

In 1912, in parallel with the space modelling, the sculptor introduced a "modulation of concavity". As a result, the researcher noted that the modelling of its outlines and the whole form became an integral part, been no less important in terms of symbolism than the form of the elevated parts. He applied this technique as to reliefs as to three-dimensional shapes. Because of numerous experiments, he received a completely new and original type of sculpture, with its new possibilities of aesthetic, optical, and spiritual expression [9, 32]. O. Arkhypenko applied his "concavity" in "sculptural painting" and in a three-dimensional sculpture. In addition, the sculptor used a double concavity, that is, the concavity within the concavity, as a rhythmic repetition $[9,33]$. The sculptor believed that in certain light the object's convex parts might seem concave and on the contrary. He deliberately used his observation in plastic forms [2]. The author advised that for a better understanding of "concavity" it was necessary to look at the psychological side of this new element of sculpture. As for the sculpture, every point on the surface should be significant and associated with millions of other surface points, altogether with similarly, relief and concavity been also interrelated.

The master often compared the sculptor with music with each note having its psychological load and at the same time associating with all other notes and pauses of the work. The same was with Oleksandr Arkhypenko's sculpture - all the concavities having an optical and psychological load and, simultaneously, connected with other, convex parts. In addition to painting, concavities in sculpture, the artist drew attention to the geometrization of his work, while observing and emphasizing that geometry is not be confused with geometrization in the Cubist style. Geometrization in his works is a consequence of the bulk sculpture technique or the use of non-plastic materials in sculptural painting. And this was not a dogmatic formula of cubism, but an inevitable technical consequence [9, 30].

The creative work of O. Arkhypenko interested his contemporaries. In 1914 in the review of the Society of Independent Artists, G. Apollinaire, the French poet, an influential figure of the European avant-garde of the early XXth century noted that the most recent and most attractive searches, in his opinion, were the Arkhypenko 's ones. As he created polychrome sculptures from various materials: glass, wood, iron, combining them in the most modern and best way $[10,20]$. The artist created not only a "sculptural painting", but he introduced quite a different term - a "moving painting". The bottom line was that the canvas with the image consisted of sliced and illuminated strips, the provisions of which the artist could change with the help of a special mechanical device [8]. Such creative searches and not standard solutions helped the artist to create his works to be admired for decades; they have not lost their relevance even in the XXI century.

Oleksandr Arkhypenko's sculpture is not a simple type of fine art, whose works been of a bulk form and done from hard or plastic materials. The sculptor had his own view as for the artistic and expressive means of sculpture, the construction of a volumetric form, plastic modelling, differently approached to the development of silhouette, texture, and colour. Due to his experiments with the form, he received a completely new principle of plastic expression; his identity was revealed in his first youthful works ("Thought", "Despair", "Zaporozhets", "Yuda"). In addition, the artist is considered to be an author of a number of "plastic new creations" such as: rhythmic form, composition intervals in the form of so-called concave (concave) and through holes, synthetic genre of sculpture and painting, active role of colour in sculpture [4]. The artist's creative heritage includes over 1000 sculptures, portraits, as well as numerous drawings, sketches ... 130 personal exhibitions were held in different parts of the world. Unfortunately, Ukraine was not included in this 
list. Only in 1987 in Lviv, in honour of the 100th anniversary of O. Arkhypenko's birth, his fans organized a small exhibition of works - mostly drawings, sketches, letters [3]. O. Arkhypenko studied and lived in France, Germany, and the USA, where he is known as an outstanding cultural figure. The artists' works may be found in the collections of such famous museums as the Pompidou Centre in Paris, the Art Nouveau and the Museum of Solomon Guggenheim in New York, as well as the museum collections of Stockholm, Tel Aviv, Moscow [4]. The sculptor's activity evidences that he did not forget about his homeland. In 1929, he presented a sculptural portrait of "Conductor W. Mengelberg performs the Beethoven's 9th Symphony" to Kyiv. There are other facts proving the sculptor to feel himself the Ukrainian. Thanks to O. Arkhypenko's active work the monuments of T. Shevchenko, I. Franko and Prince Volodymyr were placed in the parks of Chicago. In 1933, the next World Exhibition "The Centenary of Progress" was opened in Chicago, with the Ukrainian pavilion presented for the first time. It was organized by immigrants from Ukraine, representatives of the second wave of emigration. A separate hall of this pavilion was assigned to the works of Oleksandr Arkhypenko. In the same year, the artist became a member of Lviv Association of Independent Masters of Ukraine. The world remembered the sculptor as an inventor, an artist, and an extraordinary person. For us, he is not only an artist, an inventor, and a sculptor, but also a Ukrainian who became known throughout the world. Some researchers consider the artist to be the first cubist in the sculpture, although, according to his contemporaries, he did not considered himself to be a Cubists. Opposite to the other supporters of this trend, he did not consider Cubism as a dogma, but only as one of the artistic expression means. According to Arcadiia Olenska-Petryshyn, O. Arkhypenko was one of the most outstanding innovators of the modern sculpture. His innovation for a long time remained a source of inspiration for creativity of the artists' younger generations [11]. Juan Gris (Spanish artist and sculptor, one of the Cubism founders) wrote about the influence of O. Arkhypenko on the early XXth century art. In his opinion, O. Arkhypenko challenged the traditional sense of sculpture. Instead of using accustomed materials such as marble, bronze or gypsum, he addressed to such materials as wood, glass, metal, and wire. O. Arkhypenko's process of a sculpture creation looked like a visual experience of the cubist painting [1].

Conclusions. Oleksandr Arkhypenko seems to have no followers, but no art exhibit can do without the recognizable sculptural elements brought by him into plastic: void and concavities, and coloured sculptures. This is already the achievement of the universal human consciousness [2].

A characteristic feature of his works is that they always have an idea; the artist addressed to new inventions. O. Arkhypenko created his own unique, modern style, due to which his sculptures are recognizable within the world. Thus, the influence of new concepts, tendencies, shaping on various types of artistic activity, became one of the main features of the XX century sculpture development. There was a transition from the human body realistic forms imitation to the plastic ones creation, with the purpose being the expression of the emotional image and the artist's design. Figurative means differed from nature; generalization and simplification to geometric forms were used. A widespread application has become the object's fragmented vision. The usage of shaping basic means was re-thought; there appeared new means and ways of creating a sculptural form. The spatial volume plays a significant role in shaping round sculptures [7]. The XX century art of the modern has found its reflection in the works of the Ukrainian artists. The research proved that the works of the Ukrainian artists, including O. Arkhypenko, corresponded not only with world tendencies, but also made their corrections within the fine arts of Europe and the USA.

\section{References}

1. Arkhypenko, Oleksandr / Ukrainian Institute of America. April 29, 2016 - July 2, 2018. URL: http://ukrainianinstitute.org/event/Oleksandr-Arkhypenko /[in English].

2. Vezhbovska, L. (2012) Sculptor Arkhipenko. Its in Paris, Berlin and New York, a stranger in Kiev]. URL: http://texty.org.ua/pg/article/editorial/read/37501/Skulptor_Arkhypenko_Svij_u_Paryzhi_Berlini_ta [in Ukrainian].

3. Arkhypenko Oleksandr Porfirovich. Biography (1887-1964): sculptor, painter, graphic artist, art theorist / Electronic library of Knyazev. URL: http://www.ebk.net.ua/Book/synopsis/ukrainska_elita/part1/011.htm [inUkrainian].

4. Horbachova, I. Library of Ukrainian Art by Kateryna Lebedeva. URL:

http://uartlib.org/downloads/ArkhypenkoNHMU_uartlib.org.pdf [inUkrainian].

5. Kichura, L. (2012) Nikolay Holubets about Oleksandr Arkhypenko: the search for a national essence / Visnyk of Lviv University. Journalism series, Vol.33. 104-111 [inUkrainian].

6. Kubrysh, N. [National and international in the work of Oleksandr Arkhypenko]. URL: http://um.etnolog.org.ua/zmist/2011/164.pdf [inUkrainian].

7. Kuznecova, I. Means of modern round sculpture formation] [Online] URL: http://dspace.nau.edu.ua/bitstream/NAU/15608/1/\%D0\%97\%D0\%B0\%D8.

8. Sculptural Avant-Garde of Oleksandr Arkhypenko. URL: http://www.trust.ua/news/126661-skulpturnyjavangard-aleksandra-Arkhypenko-foto.html [inUkrainian].

9. Horbachov, D., Papeta, O. \&Papet, S. (Eds) (2005). Ukrainian avant-gardists as theorists and journalists]. Kyiv: Triumf [inUkrainian].

10. Fedoruk, O.K. (2006). Ukrainian avant-garde / Intersection of the sign: selected art critics. Vol.1. Kyiv: Published. house $A+C$ [inUkrainian].

11. Ferchuk, A.M. Artist and inventor Oleksandr Arkhypenko. URL:

http://www.uipv.org/i_upload/file/ferchuk(2).pdf [inUkrainian]. 